\title{
Characterization of ten extreme disturbance events in the context of social and ecological systems
}

\author{
Ariel E. Lugo
}

Received: 27 June 2017/Accepted: 17 May 2018/Published online: 1 June 2018

(C) The Author(s) 2018

\begin{abstract}
An extreme disturbance event is one in which any of its component disturbance forces and their interactions with affected systems have dimensions and responses that exceed the known range of variation expected of those parameters. If the exposed system does not respond or exhibits a low level response to an event, the event was not extreme to the exposed system, regardless of the dimensions of its disturbance forces. Extreme disturbance events are complex and require disaggregation to improve understanding of their effects. The areas affected by extreme events and the duration of the events are related but involve many orders of magnitude in terms of area affected and duration. One way to compare events is through a common and objective unit of measure such as energy. A comparison of ten extreme events in terms of their power and total energy delivered per unit area revealed a broad range of values among them. The power of events ranged 8 orders of magnitude and the total load per unit area ranged 14 orders of magnitude. Each event had different points of interaction with exposed ecosystems. When exposed to the same extreme event, the
\end{abstract}

Responsible Editor: Sujay Kaushal.

A. E. Lugo $(\bowtie)$

International Institute of Tropical Forestry, USDA Forest

Service, Calle Ceiba 1201, Río Piedras 00926-1115,

Puerto Rico

e-mail: alugo@fs.fed.us response of social systems is different from the response of the ecological systems. Also, social systems recovered quicker to a category 3 hurricane than did ecological systems. Both social and ecological systems have the capacity to evolve, adapt, innovate, and develop novelty in response to the selective pressure of extreme events.

Keywords Disturbances - Extreme events ·

Hurricanes · Landslides · Drought · Economic collapse

\section{Introduction}

Extreme disturbance events (from now on extreme events) are at center stage among social-ecological scientists dealing with issues of sustainability, climate change, and resiliency. These are the main issues being addressed in the context of the Anthropocene Epoch. At the onset of ecosystem-level ecology in the 1970s (Golley 1993) ecologists paid little attention to extreme events because ecological attention was focused on the understanding of complex mature ecosystems at steady state. In Puerto Rico, for example, the study of ecological systems progressed through a period of about 60 years uninterrupted by extreme events (Lugo 1996). This gave ecologists an opportunity to improve understanding of the functioning of rain, wet, moist, and dry tropical forests in the absence of disturbances. Ironically, while this research 
on complex mature ecosystems was underway, insular forests were recovering from one of the most significant extreme events in the island, one that went unattended by ecologists until very recently. I am referring to massive deforestation. In the 1960s the island hit bottom in forest cover (Fig. 1). This event marked the beginning of an ecological transformation of island forests that took everyone by surprise (Grau et al. 2003; Brandeis and Turner 2013).

The passage of hurricane Hugo over Puerto Rico in 1989 was a wake-up call to ecologists regarding the effects of extreme events on the functioning of island forests. This 4-h event and its ecological consequences led to a new synthesis of how tropical forests respond to disturbances (Brokaw et al. 2012). Some of the lessons learned regarding the relationship between extreme events and forest ecosystems (Lugo 2008) are relevant to this analysis and I use them as givens. For example, disturbances have visible and "invisible" effects and usually only visible effects get attention. An "invisible" effect has to be measured for it to become visible to science. Also, the ecological effects of disturbances are not as negative as they appear in the moments after the end of the event. It was clear that in spite of the physical effects of hurricanes on forest structure and the loss of the old-growth aspect of the forest, hurricanes make forests young and productive and set them in succession to recover the old growth characteristics. Moreover, disturbances sharpen the

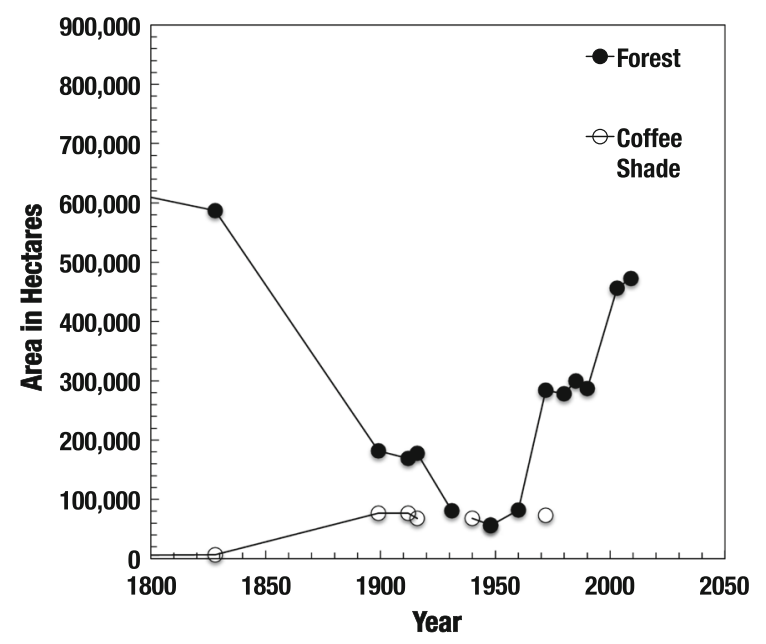

Fig. 1 Forest area of Puerto Rico between 1800 and 2009. Each point represents an estimate obtained from a variety of sources including Wadsworth (1950) for older estimates and Brandeis and Turner (2013) for the most recent estimates resilience of forests and the adaptability of their biota through their selective pressure on populations of plants, animals, and microbes. Adaptation is one of the keys for dealing with disturbance events, which in the long-term benefits the biota because adapted populations survive extreme events. We also learned that the intensity of an extreme event is not uniform over the landscape (see Fig. 4a in Peters et al. 2011). There are always locations where the intensity of the event is not as severe as in others, a reality that provides refuge to organisms experiencing the event. The severity or harshness of a disturbance event on a system depends on the type of disturbance, its strength, and the component of the exposed system that it affects (Lugo 1978; Peters et al. 2011).

I will add several observations about extreme events to the list above using a comparative socialecological approach. I aim to apply the Peters et al. (2011) framework for comparing and interpreting the social-ecological effects of ten extreme events. The Peter et al. framework is their Fig. 2, in which they disaggregate the drivers of a disturbance event that affect ecosystems, and trace their independent interaction with sectors of the ecosystem. Thus, a hurricane is not a single force affecting a forest, but it is composed of wind energy and rainfall, each with a different effect on a sector of a forest (wind affects mostly the canopy and rainfall the soil, where it can trigger other disturbances such as landslides).

The questions that I address include: What makes a disturbance event an extreme event? What do different types of extreme events have in common and how do they differ? How do extreme events affect socialecological systems and how do affected systems respond?

\section{The selected extreme events}

The following ten extreme events, arranged in chronological order, have taken place or culminated over the last 100 years in Puerto Rico and I have had the opportunity to experience them. The list is biased by my experience and is not intended to be comprehensive. For example, I do not include all drought, hurricane, or flood events through this time period. Figure 2 shows the geography over which the ten selected extreme events occurred. 


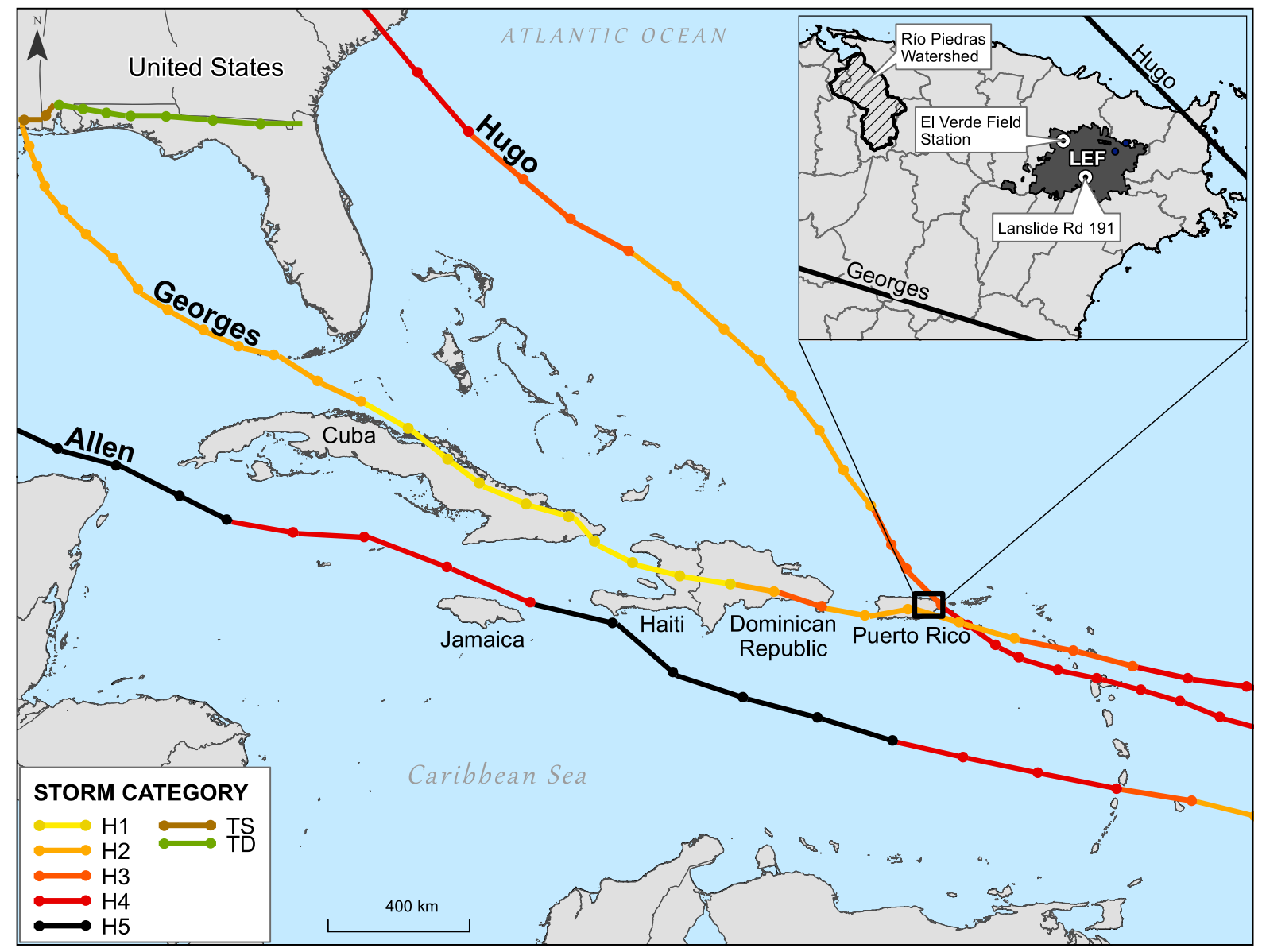

Fig. 2 Geographic location of extreme events within Puerto Rico and the Caribbean. The tracks of hurricanes depict their strength from tropical depressions (TD), tropical storms (TS) and hurricanes $(\mathrm{H})$ of different intensities in the Saffir-Simpson scale (1-5). Within Puerto Rico, the Río Piedras watershed is

Deforestation of the Island. The forest cover of Puerto Rico decreased continuously between 1800 and the 1960s (Fig. 1). The island was believed to have been $100 \%$ forest covered at the time of its discovery by Europeans (Wadsworth 1950). Forest cover declined to a historic low of about $5-10 \%$ as the Island was colonized and its economy transformed into an agrarian economy based on sugar cane, coffee, and tobacco (Picó 1969). Post agricultural economic transformation coupled to land abandonment, extensive human migration, and urbanization allowed for the recovery of forest cover to the present $60 \%$ (Grau et al. 2003; Brandeis and Turner 2013). However, the species composition of regenerated forests was within the city of San Juan, and the Luquillo Experimental Forest (LEF) is where the radiation experiment occurred at El Verde, where the $300,000-\mathrm{m}^{3}$ landslide is located, and hurricane response research is conducted

different from that of native forests before deforestation (Lugo and Helmer 2004).

Island-wide sea level rise. Since 1956, monitoring of sea levels in the Atlantic and Caribbean coasts of Puerto Rico has shown steady increases in sea levels (Fig. 3). While the slope of the increase suggests a rate of $3.2 \mathrm{~mm} /$ year (near the global average), recent values have jumped to double figures (about $10 \mathrm{~mm} /$ year). Loss of beach sand and destruction of coastal property and infrastructure are some of the visible effects of sea level rise in Puerto Rico.

Exposure to ionizing radiation with 10,000 curies of Cs. This was an experiment that lasted about 3 months during 1965 at El Verde sector of the Luquillo Experimental Forest (Odum and Drewry 1970; 


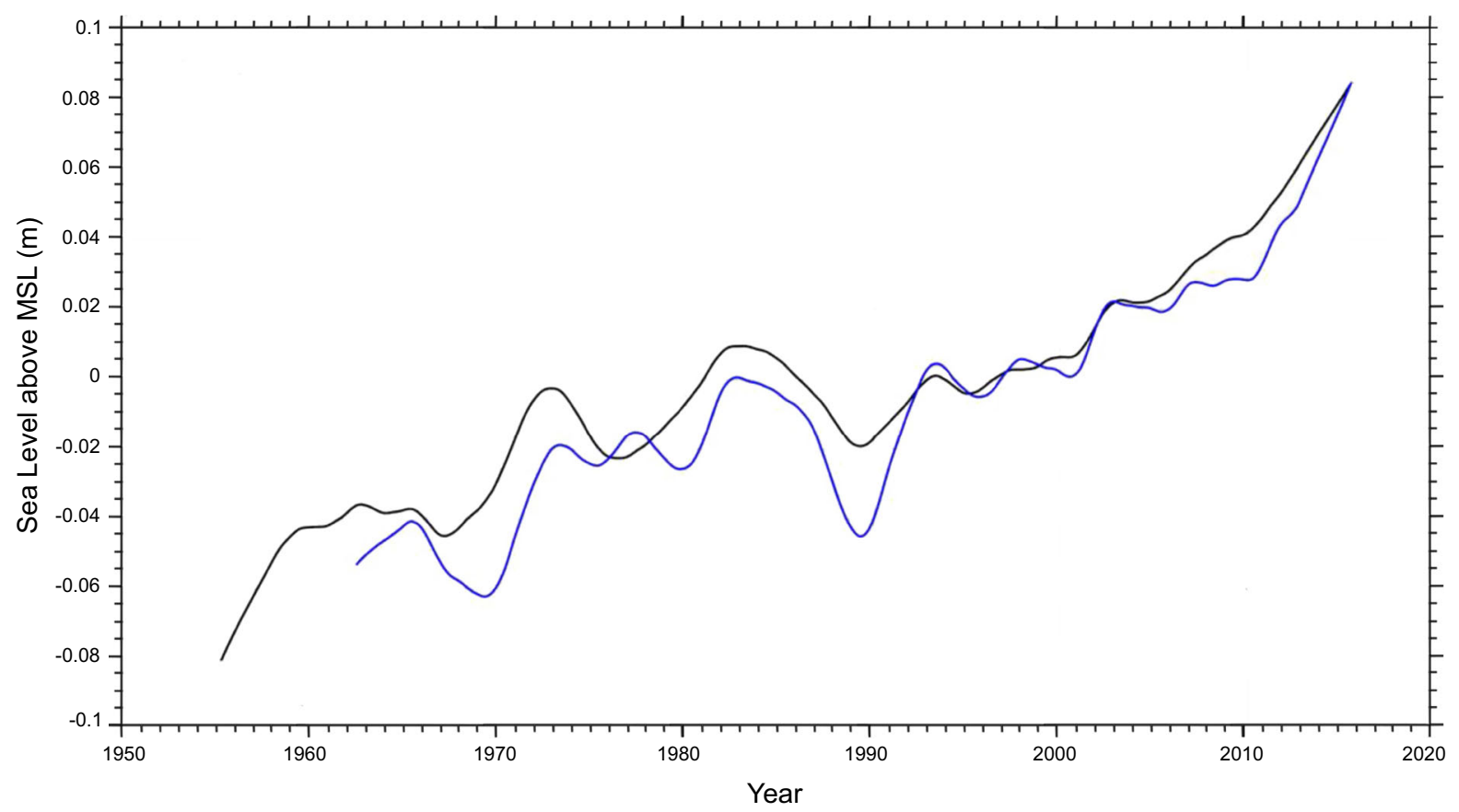

Fig. 3 Smoothed monthly sea level rise around Puerto Rico. The longer record (black line) is for Magueyes Island in the Caribbean Sea, and the shorter record in blue is for San Juan Bay

Fig. 4). Radiation levels reached a million roentgens within a meter from the radiation source. Extensive dosimetry established the radiation loads around and above the radiation source (McCormick 1970), which exposed a mature tabonuco (Dacryodes excelsa) wet forest.

A $300,000-\mathrm{m}^{3}$ landslide. Landslides are triggered when excessive rainfall that saturates soil on steep terrain overcomes a threshold of intensity and duration (Larsen and Torres Sánchez 1998). During the 1970s the passage of several low-pressure systems over the slopes of the Luquillo Mountains saturated the terrain and triggered one of the largest landslides in Puerto Rico. Within minutes, about $300,000 \mathrm{~m}^{3}$ of soil, the forests growing on that substrate, and a major highway (PR 191) rushed down the mountain slope, exposing the saprolite beneath, and leaving no trace of what was originally primary forest cover and soil (Fig. 4b in Peters et al. 2011). This event permanently interrupted highway traffic as the road was closed.

A 100-year urban flood. The 100-year flood event for the city of San Juan was simulated by the US Army Corps of Engineers as part of their analyses for the channelization of the Río Piedras river (Fig. 5). Such a flood covers approximately 240 hectares, reaches a in the Atlantic Ocean. Aurelio Mercado Irizarry of the University of Puerto Rico at Mayagüez provides these data

water depth of about $5 \mathrm{~m}$, and lasts $5 \mathrm{~h}$. Based on historical floods in the 1970s, the US Army Corps of Engineers estimates a cost to the economy of millions of dollars in lost infrastructure and economic activity as a result of this event.

Category 3-4 hurricanes. The Caribbean is in the hurricane belt of the Atlantic Ocean and is subject to frequent passages of storms and hurricanes of various categories in the Saffir-Simpson scale. I focus on the effects of category 3 and 4 hurricanes (sustained wind speeds between 196 and $251 \mathrm{~km} / \mathrm{h}$ ), specifically hurricanes Hugo, Georges, and Allen. In this comparison I address wind and waves over forests and coral reefs, respectively. High winds and tall waves have significant effects on terrestrial infrastructure, both coastal and inland.

Economic collapse of Island finances. In 2006, the economy of Puerto Rico began a contraction trend that continued uninterrupted over the next ten years, declining to 1994 economic level of activity (Fig. 6). The Island accumulated a debt of about 72 billion dollars, leading to a current state of bankruptcy and large levels of population emigration to the United States of America. 


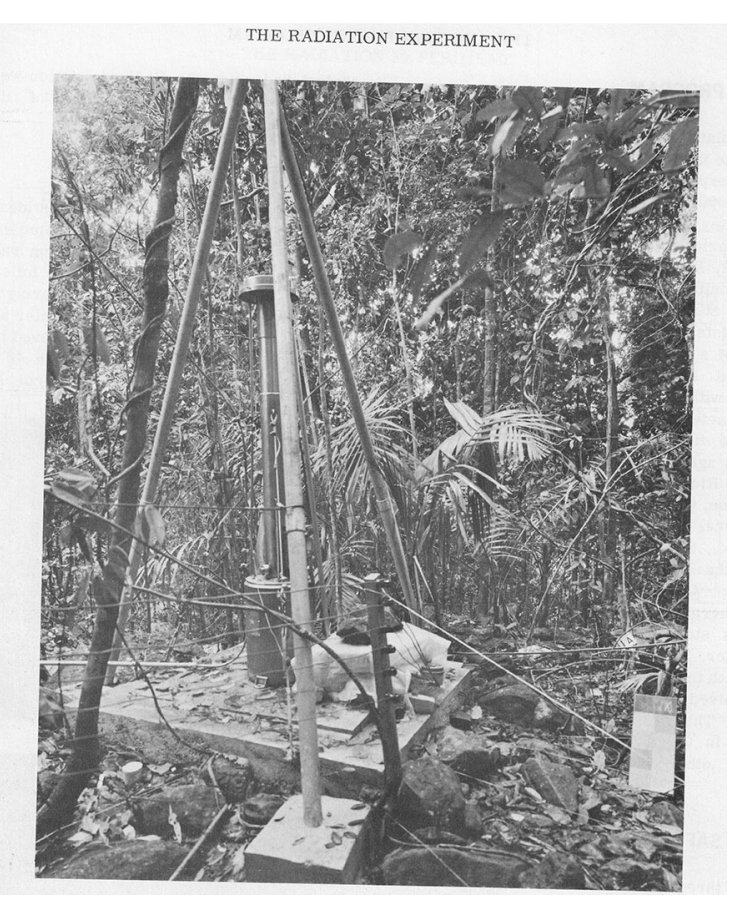

Fig. 4 Picture of the radiation source installed in a wet forest at El Verde, Luquillo Experimental Forest. The two-Mg lead container at the center of the concrete base contains the radioactive $\mathrm{Cs}$ source, which would be magnetically hoisted to below the oval metal structure when in operation (from Odum and Drewry 1970)

Heat island over San Juan. Méndez Lázaro et al. (2016) defined urban heat episodes as those with an air surface temperature greater than the 90th percentile of measured temperatures. Records for San Juan contain heat episodes of up to 40 days in 2012 with sustained air surface temperatures above $30{ }^{\circ} \mathrm{C}$ and up to $38^{\circ} \mathrm{C}$ (Méndez Lázaro et al. 2016). A surface temperature map for the city showed locations with temperatures as high as $63{ }^{\circ} \mathrm{C}$ (Méndez Lázaro et al. 2017). Increased mortality among the oldest and youngest age classes and increased electric energy consumption for air conditioners are associated with these events (Méndez Lázaro et al. 2016).

Low-pressure system over San Juan, Puerto Rico. Low-pressure atmospheric systems trigger heavy urban rains and floods, which interrupt the normal functioning of the city and cause economic losses. I use the July 18, 2013 low-pressure event that passed over San Juan. The US Weather Service measured the highest 24-h rainfall precipitation on record for the city $(234 \mathrm{~mm})$ and estimated a 50 years recurrence interval for this event.
Island-wide 1 year + drought. Atmospheric conditions in the Caribbean and around Puerto Rico resulted in a drought that began in January 2014 and ended in November 2016. At its peak level in August 2015, the drought affected almost all of Puerto Rico (Fig. 7), including the wettest sectors of the Luquillo Mountains. Water was rationed for millions of people. Affected aquifers, rivers, and streams reached the lowest levels measured in available records (Department of Natural Resources and the Environment 2016).

\section{Methods}

For each selected extreme event, I searched for records that indicated the area affected and the duration of the event. I then estimated the intensity or power of seven of the ten extreme events using the same energy units of power $\left(\mathrm{j} / \mathrm{m}^{2} \mathrm{~s}\right)$, so that they could be compared on an equal basis. Odum (1996) contains many of the formula and procedures for the energy calculations.

The level of ionizing radiation produced by the radiation source in roentgens $(r)$ was converted to Grays in $\mathrm{j} / \mathrm{kg}$ ( $1 r=0.00,877$ Grays). This energy was converted to power units $\left(\mathrm{j} / \mathrm{m}^{2} \mathrm{~s}\right)$ by multiplying by the air density in a cone $10 \mathrm{~m}$ in radius and $20 \mathrm{~m}$ canopy height around the radiation source. The radiation field emitted by the radiation source and the duration of the emission $(2228 \mathrm{~h}$ ) was obtained from Odum and Drewry (1970). McCormick (1970) reported the pattern of radiation exposure around the radiation source. The radiation measured within the volume around the source $\left(283 \mathrm{~m}^{3}\right)$ ranged from one million to $50,000 \mathrm{r}$.

To estimate the kinetic energy of a landslide and a 100-year flood, I used $\mathrm{E}=0.5\left(\mathrm{~m} / \mathrm{v}^{2}\right)$, where $\mathrm{E}$ is the kinetic energy in joules, $\mathrm{m}$ is the mass in kilograms, and $\mathrm{v}$ is the velocity in $\mathrm{m} / \mathrm{s}$. To estimate the mass of soil that slid, I multiplied the volume of the landslide $\left(300,000 \mathrm{~m}^{3}\right)$ estimated by the USGS by a bulk density of $1.28 \mathrm{~g} / \mathrm{cm}^{3}$ (Larsen and Torres Sánchez 1998), and used a velocity of $3 \mathrm{~m} / \mathrm{s}$ reported by Walker and Shields (2013). The area of the slide was estimated at 10 ha and its duration was $5 \mathrm{~min}$. For the flood, the mass of water was obtained from its area (240 ha), depth $(1 \mathrm{~m})$, and the density of water. To complete the kinetic energy calculation I used a water velocity of 


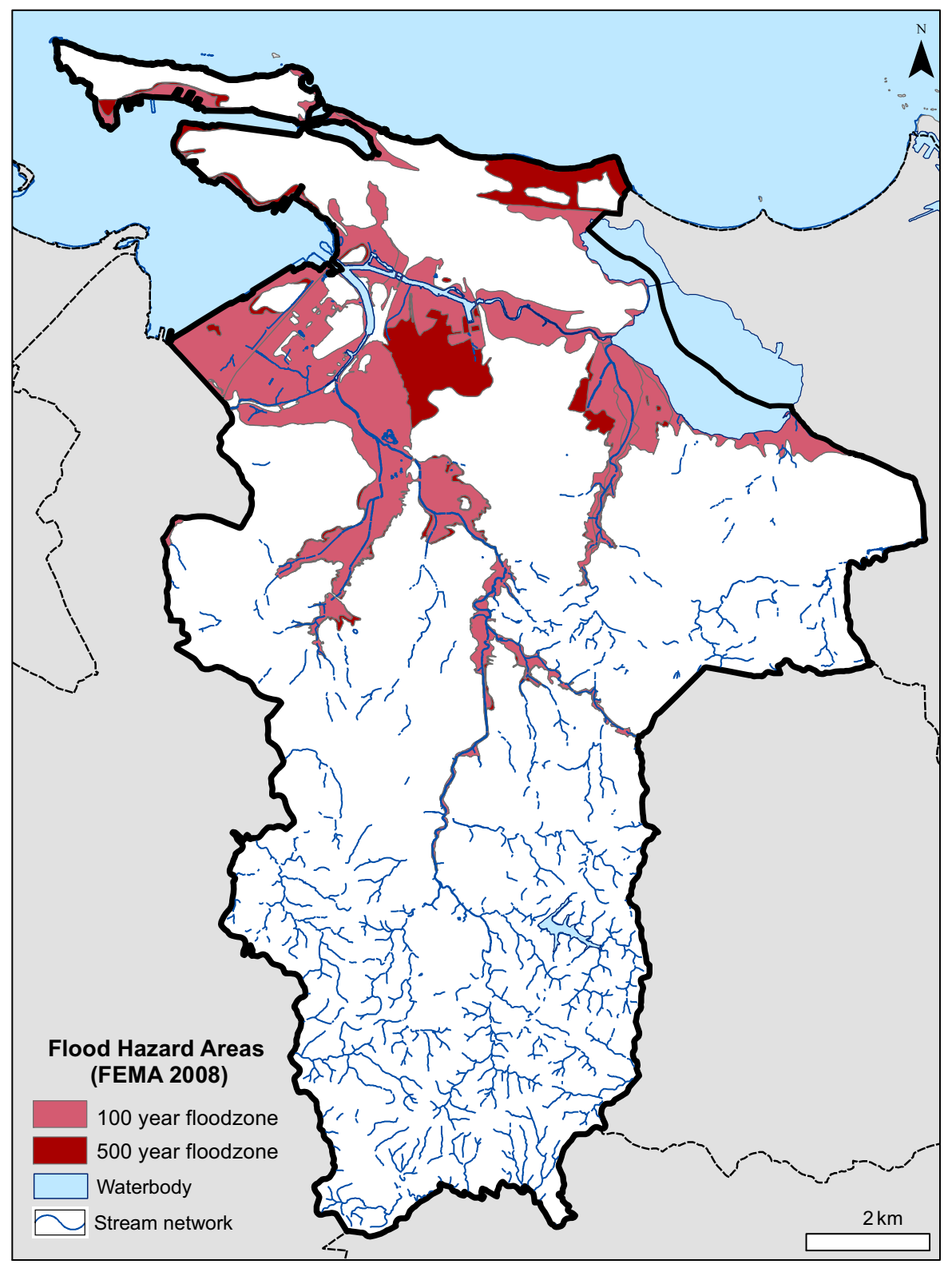

Fig. 5 Map of the 100- and 500-flood zones (red) in the municipality of San Juan. This map is by the Federal Emergency Management Agency (FEMA) produced for Flood Insurance purposes. Flood zones are defined in https://www.fema.gov/flood-zones

$1 \mathrm{~m} / \mathrm{s}$ and flood duration of $5 \mathrm{~h}$ reported by the US Army Corps of Engineers (in Lugo et al. 2013).

The power of hurricane winds and waves was obtained from Lugo et al. (2000, 2004). The estimate of the most powerful waves was based on the surge caused by hurricane Allen over Jamaica on August 6, 1980. That storm surge reached $12 \mathrm{~m}$. Calculations for the power of waves are based on equations in Dean and Dalrymple (1991) with examples in Odum (1996) and
Lugo et al. (2004). Calculations require information on wave height in $\mathrm{m}$, wave periodicity in seconds, wavelength in $\mathrm{m}$, water depth in $\mathrm{m}$, water density ( $\mathrm{g} /$ $\mathrm{cm}^{3}$ ), and acceleration by gravity.

To estimate the energy equivalency of the economic collapse of Puerto Rico, I estimated the loss in economic activity during the decade of 2006-2016 (Fig. 6). This loss was equivalent to 14.1 billion dollars. Using data compiled for a dissertation 
Fig. 6 Monthly Index of Economic Activity for Puerto Rico between February 1980 and February 2016. The Government Developmental Bank for Puerto Rico provides this record. In this record, the activity level in January 1980 is equivalent to and index of 100

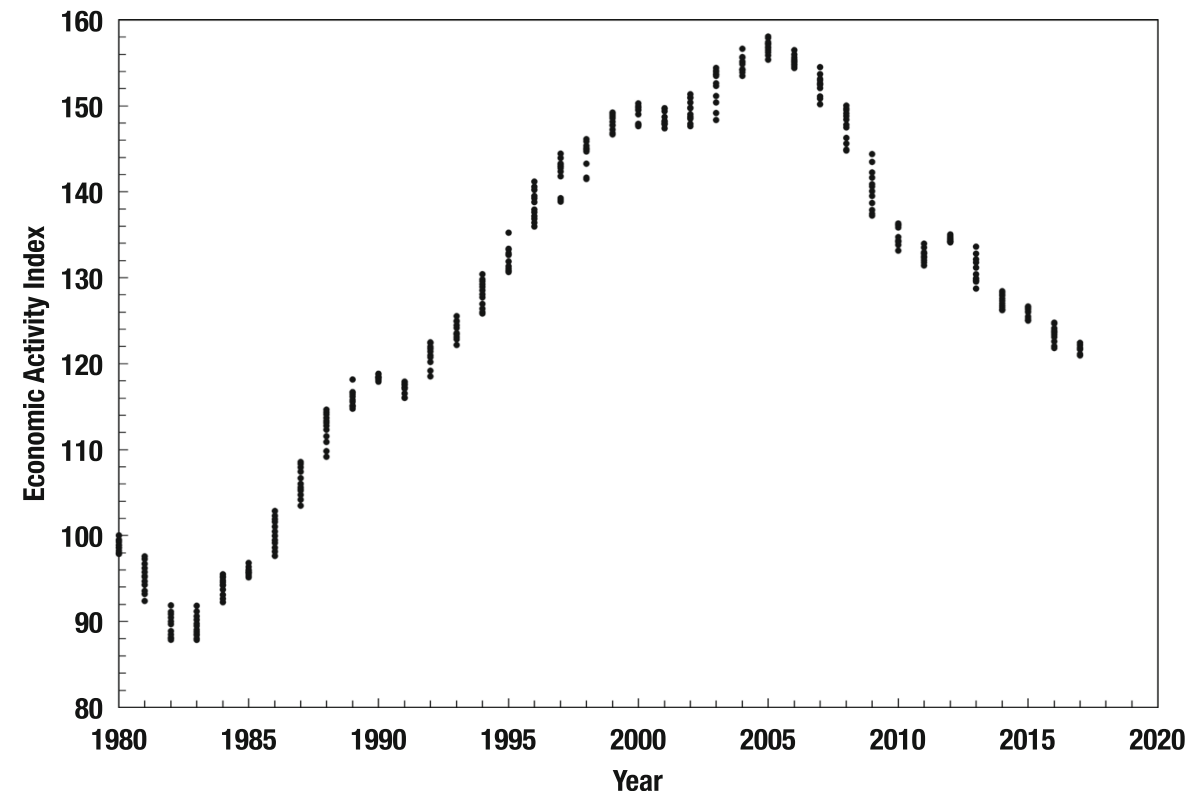

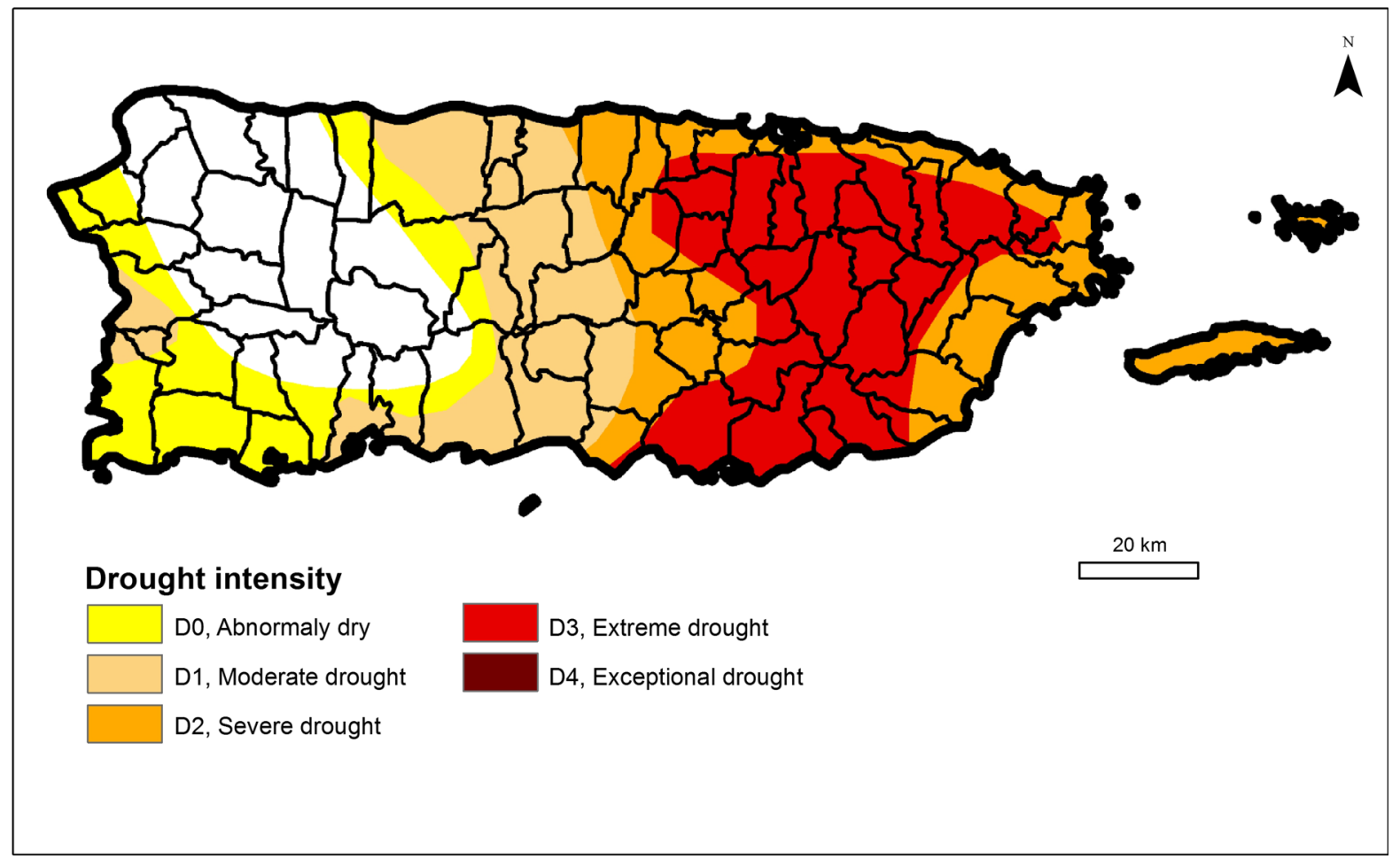

Fig. 7 Drought intensity in Puerto Rico during August, 2015. This map and others for different months are produced by the Drought Monitor and are available at http://droughtmonitor.unl.edu/

research in progress by Braulio Quintero, State University of New York at Syracuse, I averaged the annual ratio of economic activity to fossil fuel energy use by the Puerto Rico economy between 1982 and 2014. The resulting energy equivalency of one dollar in the puertorrican economy was 5.66 Tjoules. The 
energy equivalency of the economic collapse was expressed per island $\left(8800 \mathrm{~km}^{2}\right)$ and per urban $\left(1760 \mathrm{~km}^{2}\right)$ area over a decade.

The energy radiated by a heat wave was estimated with the relationship $\mathrm{E}=\alpha \mathrm{T}^{4}$, where $\mathrm{E}$ is the energy in watts $/ \mathrm{m}^{2}, \alpha=5.67 \times 10^{-8}$, and $\mathrm{T}$ is the temperature of the event in ${ }^{\circ} \mathrm{K}$. This assumes an emissivity of 1 , when in reality the emissivity of asphalt, concrete, glass, paint, and water (common urban surfaces) ranges from 0.88 to 0.96 . Applying such corrections according to their proportion on the city would not alter the order of magnitude of $\mathrm{E}$. The duration of the heat wave (30 days) and temperature $\left(38{ }^{\circ} \mathrm{C}\right)$ were obtained from Méndez Lázaro et al. (2016, 2017). The duration in seconds was used to convert watts $/ \mathrm{m}^{2}$ to joules $/ \mathrm{m}^{2}$.

To estimate the chemical potential energy of rainfall during the extended low pressure event over San Juan, I multiplied the Gibbs free energy value of pure water in relation to seawater of $4.94 \mathrm{j} / \mathrm{g}$ (Odum 1996), by the 24-h rainfall of $0.234 \mathrm{~m}$, the density of water in $\mathrm{g} / \mathrm{m}^{3}$, and the area of the city $\left(12.7 \times 10^{7} \mathrm{~m}^{2}\right)$. The result is the energy equivalency of the leaching (cleaning) capacity of rainwater as it flows over city surfaces. I also estimated the kinetic energy of falling water (its erosion potential) over city surfaces, using the relationship Energy in joules = mass of water $(\mathrm{kg})$ multiplied by the height of the clouds (assumed to be $2500 \mathrm{~m}$ ) and by the gravitational constant of $9.8 \mathrm{~m} / \mathrm{s}^{2}$. Results were converted to an area basis using the area of San Juan.

\section{What is an extreme event?}

An extreme event is a subcategory of disturbance events. To properly define an extreme event requires an understanding of what constitutes a disturbance. Disturbances are defined as any relatively discrete event in time that disrupts ecosystem, community or population structure and changes resource, substrate availability, or the physical environment (White and Pickett 1985). Peters et al. (2011) sharpened this definition by pointing out two refinements. First, that the discrete event needs to be defined either based on the onset, duration, or release of a driver (force) or on the time over which a mechanism operates relative to the lifespan of organisms dominating system behavior. Second, is the need to define the nature of the disruption relative to a system property in time and space.

The Peters et al. (2011) modifications to the definition of disturbance are implemented by disaggregating disturbance events into their component forces and identifying the sectors of the affected ecosystem that interact with each of the forces of disruption. Peters et al. (2011) provide many examples of this approach, which I discuss further later.

One can identify five points of interaction or "sectors" within an ecosystem where external disturbance forces interact with the biota and other components of the ecosystem (Fig. 8). These interactions can be categorized in order of severity because the effects at the point of interaction within the ecosystem affect other sectors of the system and thus it's functioning (Lugo 1978). One can expect that as energy cascades through the ecosystem from producers to consumers, to eventual dissipation as heat, those disturbances that affect fluxes upstream in the cascade will have greater effects than the ones that interrupt downstream in the cascade. While the model in Fig. 8 does not contain social elements, the functioning of social systems relative to energy transformations will not differ, as the laws of mass and energy transformation are universal. Anthropogenic systems are thus subject to metabolic analyses as are non-anthropogenic ones (Lugo 1988; Baccini and Brunner 2012). As I proceed with my analysis I will provide examples from both the social and ecological systems.

The ranking of disturbance forces in Fig. 8 in terms of severity and starting with the most severe (left to right on Fig. 8), would be: (1) Those disturbances that change or transform the main energy source of an ecosystem and in so doing change the nature of the ecosystem. These are state-changing disturbances such as transforming a flowing system into a ponded one, or changing the REDOX (reduction-oxidation) potential of a soil from aerobic to anaerobic, drying a wetland and converting it into a dry land system, or cutting off the input of fossil fuels to a city. (2) Disturbances involving a reduction in the main system driver. For example, draining freshwater from an estuary, diverting water from an agricultural field, or skimming large quantities of money from an urban economy. (3) Disturbances that affect the energy transformers of the system (plants in non-anthropogenic systems and electric energy producers in anthropogenic systems) such as timber harvesting, 


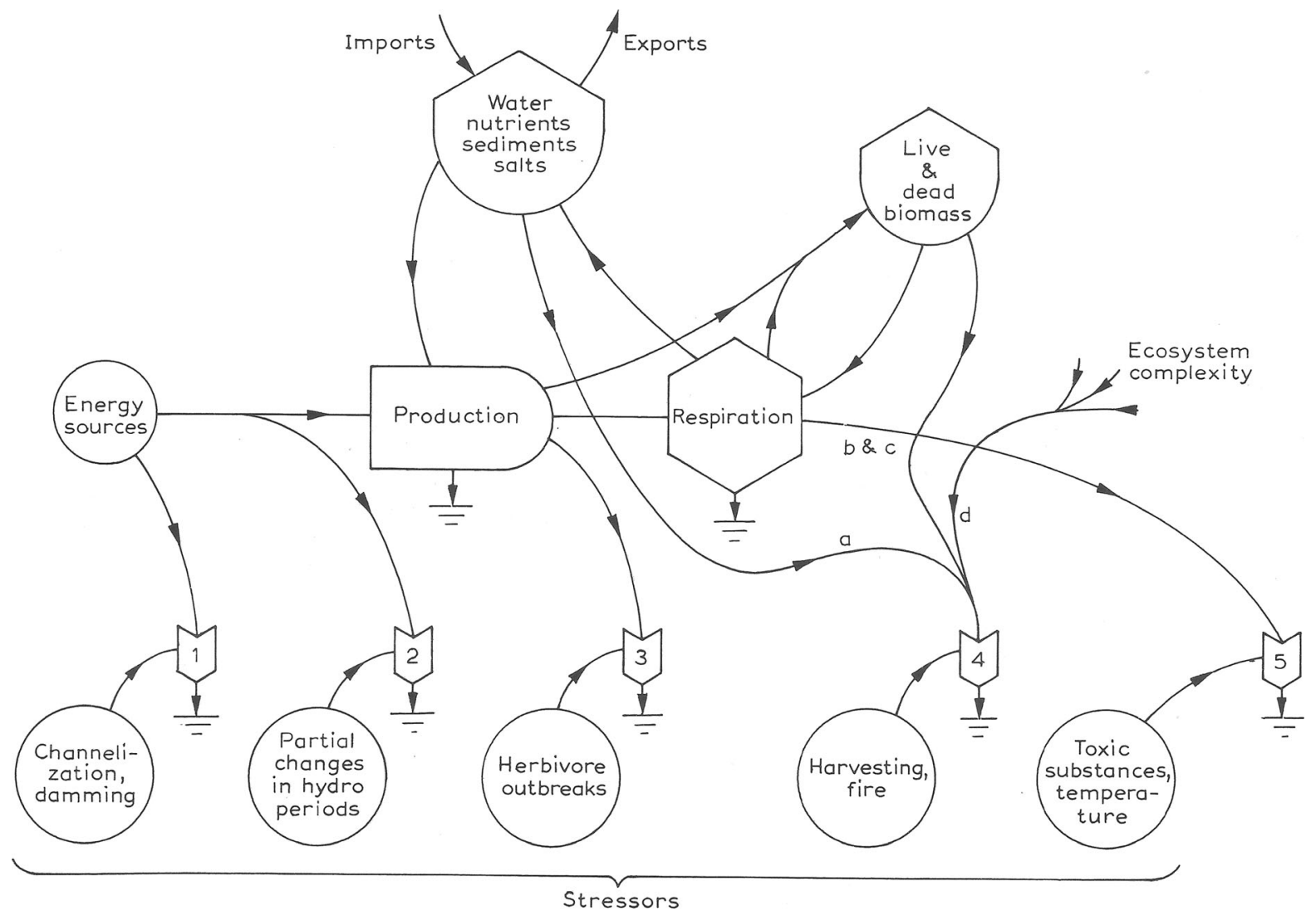

Fig. 8 Model of a wetland ecosystem illustrating five points of interaction between disturbances and ecosystem structure and functioning. A number inside the interaction symbol indicates the severity of each stressor and the identity of the stressor is

defoliation, or excessive herbivory for plants, and power failures for electric generation. (4) Disturbances that affect the state variables of the ecosystem. Examples include the depletion of nutrients by soil erosion, harvesting of wildlife, or money or fuel supply in cities. (5) Disturbances with physiological effects such as droughts, toxic substances, heat, or ionizing radiation. Table 1 categorizes the main point of interaction of the ten selected extreme events. All five points of interaction are illustrated.

The disaggregation of a disturbance event into its component disturbance forces and their coupling to those sectors of ecosystems that interact with each individual disturbance force improves understanding of the effects of the disturbance but complicates the definition of an extreme event. The reason is that what appears to be an extreme event (say a hurricane) may in fact be many interacting events (wind, rain, floods) inside the circles on the bottom of the diagram. The severity of the disturbance increases numerically from one to five, and examples of the disturbances are given (from Lugo et al. 1990)

with some being extreme while others are not. Disaggregation implies that for each component of a disturbance we need to know its intensity, duration, area affected, frequency or return interval, type of disturbance, and point of interaction with the affected system. We also need information about the affected system. For example, the sector(s) affected, level of visible effects, level of delayed effects, "invisible" effects (if measured), rate of response (positive, negative or neutral), and any change in the state of the system. Moreover, any one of those parameters that define a disturbance and its effects on ecosystems can be the reason for judging the event as extreme; it all depends on their magnitude relative to past events and ecosystem response.

In conclusion, both its characteristics and its effects on exposed ecosystems define an extreme event. Therefore, an extreme event is one in which any of 
Table 1 Criteria used to designate disturbance events as extreme events and the point of interaction of the event with the idealized ecosystem model component of Fig. 8

\begin{tabular}{|c|c|c|}
\hline Event & Why it is extreme? & Point of interaction \\
\hline Deforestation of the Island* & Area affected & 3 , reduction of state variables (above and belowground) \\
\hline Island-wide sea level rise* & Area affected & $\begin{array}{l}1,3 \text {, and } 5 \text {, change in state through salinization, reduction } \\
\text { of state variables, and physiological effects of salinity }\end{array}$ \\
\hline Exposure to ionizing radiation & $\begin{array}{l}\text { One million times background } \\
\text { radiation }\end{array}$ & 5, physiological stress \\
\hline A $300,000-\mathrm{m}^{3}$ landslide* & Its size & 1 , change in state (from forest to saprolite) \\
\hline 100-year urban flood & Recurrence interval and area flooded & $\begin{array}{l}4 \text { and } 5 \text {, reduction of state variables and physiological } \\
\text { stress of anoxic and polluted waters }\end{array}$ \\
\hline A category 3-4 hurricane & Recurrence interval and wind speed & 3 , reduction of state variables \\
\hline $\begin{array}{l}\text { Economic collapse of island } \\
\text { finances* }\end{array}$ & Duration and level of economic loss & 2 , reduction of revenue to the economy \\
\hline Heat island over San Juan* & $\begin{array}{l}\text { 90th percentile intensity and } \\
\text { duration }\end{array}$ & 5, physiological stress \\
\hline $\begin{array}{l}\text { Low-pressure system over San } \\
\text { Juan }\end{array}$ & $\begin{array}{l}50 \text {-year recurrence and amount of } \\
\text { rainfall }\end{array}$ & $\begin{array}{l}3 \text { and } 4 \text {, reduction of state variables and changes in flux } \\
\text { rates }\end{array}$ \\
\hline Island-wide 1-year + drought* & Duration and area affected & 2 and 5 , reduction of water input and physiological stress \\
\hline
\end{tabular}

Those events marked with an asterisk (*) behave as "invisible" events until a threshold of detection or effects passes and the event is "discovered"

its component forces and their interaction with affected systems has dimensions that exceed the known range of variation expected of those parameters. A problem with this definition is that there are insufficient data to define the known range of variation of most events as well as insufficient knowledge to identify critical thresholds of response of affected systems. We are left with imperfect information to make determinations. In Table $1, \mathrm{I}$ list the criteria that led me to classify as extreme each of the ten events that I analyze in this essay. Two points are notable. First, there are no consistent criteria for determining what extreme is, as each event is extreme for a reason particular to the event. Moreover, an extreme event can affect any sector of the ecosystems based on Fig. 8.

Second, extreme events can be "invisible" for considerable periods of time, i.e., an extreme event may be in progress without it being detected. Some would argue they are "invisible" until they pass an effects threshold. Such is the case of a drought, a landslide, a heat wave, economic collapse, sea level rise, and deforestation. In all these cases the extreme nature of the event is revealed after it is in progress by its effects and responses. Once the effects of an event are discovered, the determination of whether the event it is or not an extreme event will depend on measurements of the magnitude of its component disturbance forces and their effects on ecosystems.

\section{Disaggregating extreme events}

An extreme event, regardless of type (meteorological, hydrological, geological, social, or experimental), is a complex event with multiple forces and effects. That complexity has an influence on how organisms are affected by the event and is revealed when the event is disaggregated, as suggested by Peters et al. (2011). When hurricane Hugo passed near the Luquillo Experimental Forest as a category-3 hurricane its passage had a return probability of 60 year while its hurricane winds had a return probability of 50 years (Scatena and Larsen 1991). In contrast, the accompanying rainfall and stream discharge events had return times of 10 and 31 years, respectively (Scatena and Larsen 1991). Landslides associated with hurricane Hugo in turn responded to rainfall intensity and duration (Larsen and Torres Sánchez 1998). Therefore, the ecosystems and their component biota facing this once in 60-year hurricane event in some cases were facing moderate stream discharges, in other cases extreme wind conditions, and a relatively frequent rainfall intensity. These differences in severity 
translate to different effects on organisms and other ecosystem components.

For example, the intensity and affected area of the 400 plus landslides were mostly shallow landslides affecting a limited forest area depending mostly on slope, aspect, and proximity to the hurricane track (Larsen and Torres Sánchez 1998). For comparison, the largest landslide associated with hurricane Hugo had a volume of $30,000 \mathrm{~m}^{3}$, while the landslide that resulted from a low-pressure system that I analyzed was ten times larger and was not associated with a hurricane. Regarding the effects on the biota, studies revealed that shrimp, walking sticks, frugivore birds, tabonuco trees, and insectivorous predators, in spite of being located in close proximity experienced different levels of disruption by the hurricane (Brokaw et al. 2012). Levels of disruption varied from slight (tabonuco trees and shrimp) to severe (walking sticks, frugivore birds), to positive (insectivorous predators).

A chronic event such as a drought cascades through the landscape as different systems exceed their tolerance thresholds and exhibit effects at different times. As it evolves, what appears as one disturbance (drought) becomes many disturbances in relation to affected ecosystems. For example a meteorological drought, followed by a hydrologic drought, followed by an agricultural drought, an urban drought, and a forest drought. The reversal of the drought also occurs in a cascade of response. As it interacts with different systems, different tolerance thresholds are exceeded and different ecosystem components and processes are affected.

Excessive borrowing by the Commonwealth government subsidized the economy and hid the 10-year economic downturn that led to bankruptcy. In this case the disaggregation of an extreme economic event involves all the actions of government designed to counter the economic decline. Borrowing, annual government budgets, laws and regulation, and government efficiency and ethics are all part of the complexity associated with economic collapse.

\section{Comparison of extreme events}

Duration and area affected

In terms of the duration and area affected by the ten events of this study, there is no commonality among them. The duration of the selected extreme events ranges from minutes to centuries, affect areas that range from hundredths of hectares to almost tens of thousands of hectares (Fig. 9). I grouped those events lasting a year or less as acute events, and those lasting greater than 1 decade as chronic events. All chronic events affect large areas. Excluding the radiation experiment, there is a significant $(p<.05)$ power relation between affected area in $\mathrm{km}^{2}$ and duration in days $\left(y=41.2 \mathrm{x}^{0.49} ; R^{2}=0.53\right)$.

\section{Energy level}

Extreme events also varied in power or dissipated energy. The range in power level among extreme events ranged eight orders of magnitude (Fig. 10). The highest power was associated with hurricane waves and the least with flooding. Notably, hurricane winds are not as comparatively powerful as one would have expected, and the economic collapse, when expressed over the urban area has the same power as $1 \mathrm{~m}$ waves. This does not mean that they have the same effects because they represent different kinds of energy and interact with different types of systems. The duration of events determined the total energy dissipated over affected systems and this estimate changed the order of events compared to their power delivery (Fig. 10). The range of the absolute energy load of extreme events was 14 orders of magnitude. Chronic events such as the economic collapse gained importance relative to the physical events associated with hurricanes. Low power events with a longer duration

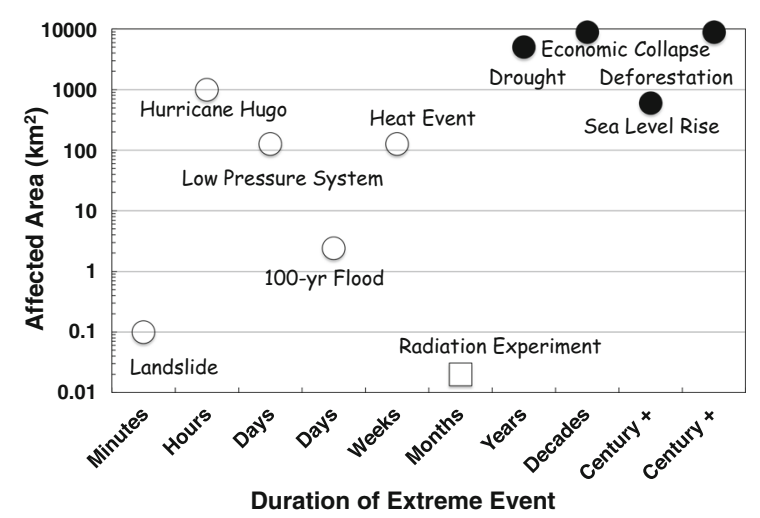

Fig. 9 Relation between the area affected and duration of ten extreme events that affected Puerto Rico over the last 100 years. Solid circles represent chronic events, open circles are acute events, and the open square represents an acute ionizing radiation experiment 
Fig. 10 Power (blue bars) and absolute load (red bars) of extreme events or their component disturbance forces. These estimates are based on real values observed in Puerto Rico over the last 100 years

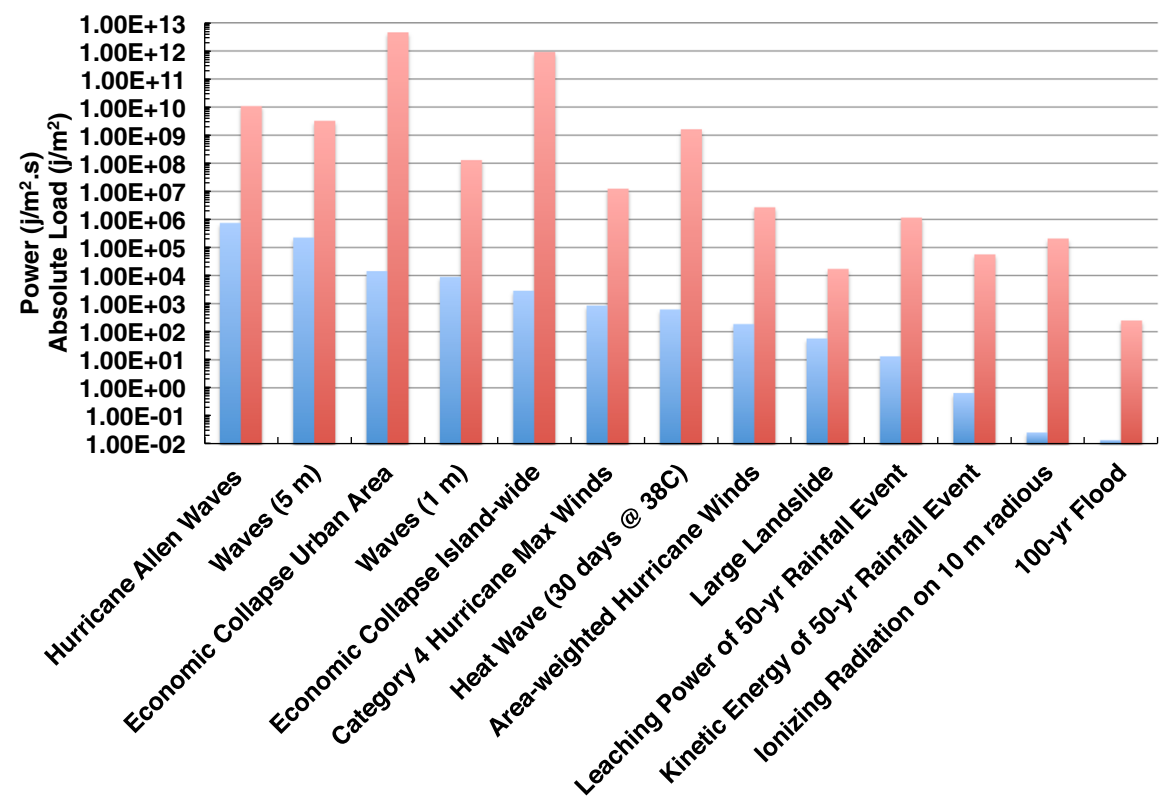

increased their rank order relative to higher power events with shorter duration (e.g., compare the leaching power and kinetic energy of 50-year rainfall event with the landslide).

\section{Effects}

Being affected or not by an extreme event is haphazard. But when exposed to an extreme event, the effects can be different for social and ecological systems (Table 2). In fact, in the case of floods the ecological system might benefit while the social systems can experience losses in life and property. Economic collapse benefited some sectors of a social system (banks, financial and legal firms) while most citizens, insurance companies, and institutions experience losses, and the ecological system experiences no effects or a positive response to lower intensity of human activity. The effects on exposed systems also define if an event is extreme or not. For example, an extreme drought for agricultural, social, and hydrological systems may not have significant effects on forests, even though the drought had a low frequency of occurrence. This was evident during the 2015 drought in Puerto Rico. While there were measurable losses in agriculture and commerce, and profits in the service sector of the economy, ecologists had a difficult time documenting severe effects on forests. Drought effects such as increased leaf fall and differential mortality of some species of plants and animals were not severe and were quickly reversed with the onset of rains. Thus, such an extreme drought to social and hydrological systems would not qualify as an extreme event for forests. Similarly, an extreme flood event on a neighborhood adapted to floods would not be considered extreme unless it overwhelms its adaptations to flooding.

\section{Adaptability}

The level of adaptability to flooding in social systems and to drought in ecological systems determines the level required for an event to become an extreme event in terms of effects. This is so because the affected systems have memories (genetic memory in ecological systems and cultural memory in social ones) from the past that have resulted in adaptation for particular levels of intensity and frequency of events that when they occur might appear extreme for systems without adaptation, but are within the range of functioning for those with the adaptations. An ecological example is the response of Palicourea riparia, a tree, to high levels of ionizing radiation. This tree grew faster, sprouted, reproduced, established populations, and gained dominance closer to the radiation source than any other tree species in the tabonuco forest (Jordan 1970; Mercado 1970; Watson 1970). Its genetic make up was pre-adapted to ionizing radiation (Koo and De 
Table 2 Social and ecological effects of ten extreme events that occurred in Puerto Rico over the past 100 years

\begin{tabular}{|c|c|c|}
\hline \multirow[t]{2}{*}{ Event } & \multicolumn{2}{|l|}{ Effects } \\
\hline & Social & Ecological \\
\hline Deforestation of the Island & $\begin{array}{l}\text { A necessity for survival; part of the economic } \\
\text { strategy of the government }\end{array}$ & $\begin{array}{l}\text { Dramatic changes in species abundances and } \\
\text { distribution, emergence of novel forests }\end{array}$ \\
\hline Island-wide sea level rise & $\begin{array}{l}\text { Millions lost in property and economic } \\
\text { opportunity; disruption of vital infrastructure }\end{array}$ & $\begin{array}{l}\text { Beach ecosystem affected, changes in coastal } \\
\text { vegetation and animal distribution }\end{array}$ \\
\hline $\begin{array}{l}\text { Exposure of a forest to ionizing } \\
\text { radiation }\end{array}$ & No effect & $\begin{array}{l}\text { Vegetation changed from forest to herbaceous; } \\
\text { biomass recovery was slowed; the growth and } \\
\text { radiation resistance of Palicourea riparia was a } \\
\text { surprise }\end{array}$ \\
\hline A $300,000-\mathrm{m}^{3}$ landslide & $\begin{array}{l}\text { No effect. However, a similar landslide in an } \\
\text { urban setting caused hundreds of lives lost }\end{array}$ & $\begin{array}{l}\text { Succession flipped from primary forest to } \\
\text { primary succession; a loss of over } 500 \text { years of } \\
\text { succession }\end{array}$ \\
\hline 100-year urban flood & $\begin{array}{l}\text { Loss of property and infrastructure, reduced } \\
\text { productivity }\end{array}$ & Increased productivity and nutrient enrichment \\
\hline A category 3-4 hurricane & $\begin{array}{l}\text { No lives lost, millions of dollars in property } \\
\text { loss }\end{array}$ & $\begin{array}{l}\text { Visible and "invisible" effects; positive long- } \\
\text { term ecological effects }\end{array}$ \\
\hline $\begin{array}{l}\text { Economic collapse of island } \\
\text { finances }\end{array}$ & $\begin{array}{l}\text { Potential social chaos and collapse; massive } \\
\text { human population emigration; disruption of } \\
\text { government services; individual and } \\
\text { institutional economic loss }\end{array}$ & $\begin{array}{l}\text { No immediate effect, long-term reduction of } \\
\text { anthropogenic stressors }\end{array}$ \\
\hline Heat island over San Juan & $\begin{array}{l}\text { Lives lost (young and old people); increased } \\
\text { energy consumption }\end{array}$ & Increased respiration \\
\hline $\begin{array}{l}\text { Low-pressure system over San } \\
\text { Juan }\end{array}$ & Life and property loss & Increased productivity \\
\hline Island-wide 1-year + drought & $\begin{array}{l}\text { Millions of dollars lost in economic activity; } \\
\text { enormous inconvenience to people, and } \\
\text { alteration of social activities }\end{array}$ & $\begin{array}{l}\text { Minor effects on vegetation and on some animal } \\
\text { species; dramatic change in soil oxygen and } \\
\text { microbial activity of rain forest soils }\end{array}$ \\
\hline
\end{tabular}

Irizarry 1970; Venator and Koo 1970) and thus gave the species an advantage in post-radiation succession (Odum 1970). Examples of memory and adaptability in social ecological systems are discussed in Gunderson and Holling (2002).

\section{Recovery}

The recovery from the hurricane required more time in ecological than in social systems (Table 3). Social systems can concentrate fossil fuel energy and effort to repair structures and functions, while ecological systems must do so with solar energy, which is a diluted energy source, and through time-consuming ecological processes such as succession and selforganization. The influx of borrowed money during the developing economic collapse of Puerto Rico represented an energy subsidy to help repair or overcome the effects of a reduced economic output. Other extreme events such as hurricanes, do not affect long-term ecological processes in progress after deforestation and land degradation. In this example, the hurricane can affect the structure of existing systems, but the successional development of affected systems continues its slower and long-term response to past deforestation and land degradation (Thompson et al. 2002).

Site degradation (deforestation, landslides) and physiological stress (ionizing radiation, extreme drought) can delay recovery in ecological and agricultural systems. For example, the influx of ionizing radiation had a retarding effect in the post radiation biomass accumulation of the tabonuco forest (Lugo and Heartsill Scalley 2014). Moreover, some extreme events erase previous ecological systems and processes causing a change in ecosystem state or long recovery time (landslides, volcanic eruption). 
Table 3 Time required for recovery after ten extreme events that occurred in Puerto Rico over the past 100 years

\begin{tabular}{|c|c|c|}
\hline \multirow[t]{2}{*}{ Event } & \multicolumn{2}{|l|}{ Recovery time } \\
\hline & Social system & Ecological system \\
\hline Deforestation of the Island & $\begin{array}{l}\text { No visible effect because the economy } \\
\text { shifted energy sources }\end{array}$ & $\begin{array}{l}100 \text { years; shift to novel systems appears } \\
\text { permanent }\end{array}$ \\
\hline Island-wide sea level rise & 100 years & Shift in ecological zones \\
\hline $\begin{array}{l}\text { Exposure of a forest to ionizing } \\
\text { radiation }\end{array}$ & No effect & $\begin{array}{l}\text { Probably } 100 \text { years, since forest biomass } \\
\text { has not recovered after } 50 \text { years }\end{array}$ \\
\hline A $300,000-\mathrm{m}^{3}$ landslide & No effect & $\begin{array}{l}100 \text { years to forest cover and functioning; } \\
\text { longer to original structure and } \\
\text { composition }\end{array}$ \\
\hline 100-year urban flood & $\begin{array}{l}\text { Six months for cleanup and repair; some } \\
\text { communities experience significant } \\
\text { losses and longer recovery }\end{array}$ & $\begin{array}{l}\text { No visible effects, functions continue } \\
\text { uninterrupted }\end{array}$ \\
\hline A category 3-4 hurricane & Several years & 60 years on average \\
\hline $\begin{array}{l}\text { Economic collapse of island } \\
\text { finances }\end{array}$ & Decades & No visible effect \\
\hline Heat island over San Juan & $\begin{array}{l}\text { Recovery is rapid, except for those with } \\
\text { chronic ailments }\end{array}$ & $\begin{array}{l}\text { No visible effects, high respiration rates } \\
\text { probably return to normal when the } \\
\text { temperature decreases }\end{array}$ \\
\hline $\begin{array}{l}\text { Low-pressure system over San } \\
\text { Juan }\end{array}$ & $\begin{array}{l}\text { Six months for cleanup and repair; some } \\
\text { communities experience significant } \\
\text { losses and longer recovery }\end{array}$ & $\begin{array}{l}\text { No visible effects, functions continue } \\
\text { uninterrupted }\end{array}$ \\
\hline Island-wide 1-year + drought & $\begin{array}{l}\text { Over a year to recover lost revenues and } \\
\text { agricultural production }\end{array}$ & $\begin{array}{l}\text { No visible effects. Increased leaf drop } \\
\text { returns to normal within weeks }\end{array}$ \\
\hline
\end{tabular}

\section{Implications to the study of social and ecological systems}

The Anthropocene Epoch represents a challenge to the functioning of social and ecological systems because changing environmental conditions test resilience and adaptability of the biotic and non-biotic components of those systems. The shifting of environmental regimes will also involve shifting disturbance regimes, with some disturbances becoming more extreme in both their nature and effects. These tendencies require precise disaggregation of disturbance forces and their effects, with the understanding that these events have positive as well as negative effects on social and ecological systems. In fact, extreme events are agents of evolutionary change and innovation by exerting strong selective pressure on organisms and on social learning (Fig. 11). Both social and ecological systems gain adaptation to changing conditions when natural selection forces select the most successful alternative solutions for coping with the environment (Fig. 11). Extreme environments expose systems to stronger gradients of environmental change and thus accelerate the processes that result in adaptability and innovation (see Gunderson and Holling 2002 for underpinning theory).

One of the consequences of the passage of extreme events is the generation of novelty in response to the extreme conditions that they generate. This was the case with the emergence of novel forests after massive deforestation in Puerto Rico (Lugo and Helmer 2004). Soils had been so eroded after deforestation and agricultural use that most native tree species could not reassemble the original forests. Instead, non-native tree species colonized degraded sites and over decades contributed to the assembly of forests with novel species combinations that included both native and non-native species. An analogous response in social systems is the flood proofing of buildings and infrastructure after extreme floods, or the passing of laws and regulations after economic collapse to avoid repeating past financial mistakes. Novelty and adaptability are linked responses to extreme events that lead to resiliency and survival in social and ecological systems. 


\section{ADAPTING TO ENVIRONMENTAL CHANGE}

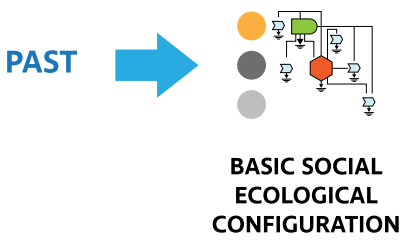

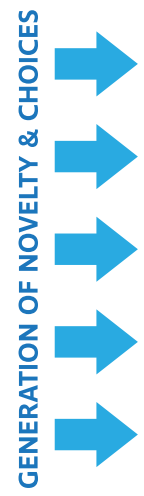

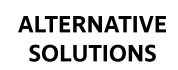

TO PROBLEMS

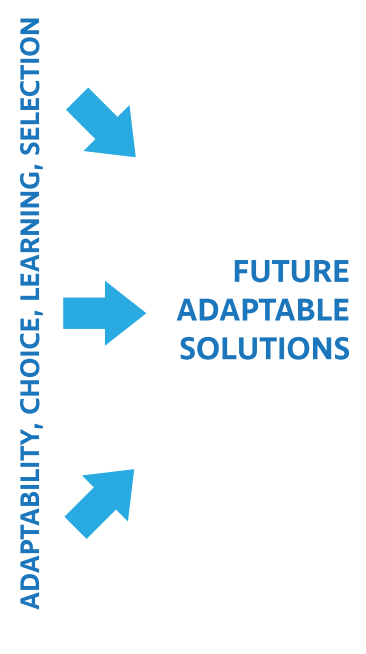

Fig. 11 Heuristic schematic of the evolution of solutions to flooding in a social ecological system (from Muñoz-Erickson et al. 2014). The basic social ecological configuration is subjected to extreme flooding events (left side of the diagram). As a result, a variety of alternatives solutions to flooding are

\section{Conclusions}

The comparison of different extreme events and how they interact with social and ecological systems leads me to three conclusions. First, extreme events are inherently complex and need to be characterized by the intensity, frequency, and extent of its component driving forces as well as by their distinct effects on components of social and ecological systems. Second, the response of social and ecological systems to extreme events is different and depends on what sectors of those systems are affected by the forces of the event and the energy available to overcome the effects. In some cases, extreme events that affect social systems do not affect ecological ones or vice versa. Third, understanding the effects of extreme events requires objective non-normative analysis of their causes and effects including long-term effects.

Acknowledgements This study was conducted in collaboration with the University of Puerto Rico. Braulio Quintero, State University of New York, made possible the conversion of dollars to energy in the Commonwealth economy. The following colleagues reviewed and improved the manuscript: Ernesto Medina, Pablo Méndez Lázaro, and Lauren McPhillips. This manuscript is a contribution of the San Juan ULTRA program of the International Urban Field Station, and was supported in part by the National Science generated. These alternative solutions involve novelty and constitute available choices. The right side of the diagram illustrates the role of adaptability, choice, learning, and selection in the development of future adaptable solutions

Foundation Grant 1444755 to the Urban Resilience to Extreme Weather-Related Events Sustainability Research Network.

Open Access This article is distributed under the terms of the Creative Commons Attribution 4.0 International License (http:// creativecommons.org/licenses/by/4.0/), which permits unrestricted use, distribution, and reproduction in any medium, provided you give appropriate credit to the original author(s) and the source, provide a link to the Creative Commons license, and indicate if changes were made.

\section{References}

Baccini P, Brunner PH (2012) Metabolism of the anthropocene, 2nd edn. The MIT Press, Cambridge

Brandeis TJ, Turner JA (2013) Puerto Rico's forests, 2009. Southern Research Station, USDA Forest Service Resource Bulletin SRS-191, Ashville, NC

Brokaw N, Crowl TA, Lugo AE, McDowell WH, Scatena FN, Waide RB, Willig MR (eds) (2012) A Caribbean forest tapestry: the multidimensional nature of disturbance and response. Oxford University Press, New York

Dean RG, Dalrymple RA (1991) Water wave mechanics for engineers and scientists. World Scientific Publishing Co Pte Ltd, Singapore

Department of Natural Resources and the Environment (2016) Informe sobre la sequía de 2014-2016 en Puerto Rico. División de Monitoreo del Plan de Aguas, San Juan, PR. $82 \mathrm{pp}$

Golley FB (1993) A history of the ecosystem concept in ecology: more than the sum of the parts. Yale University Press, New Haven 
Grau HR, Aide MT, Zimmerman JK, Thomlinson JR, Helmer E, Zou X (2003) The ecological consequences of socioeconomic and land-use changes in postagriculture Puerto Rico. Bioscience 53:1159-1168

Gunderson LH, Holling CS (eds) (2002) Panarchy. Understanding transformations in human and natural systems. Island Press, Washington, DC

Jordan CF (1970) Vegetation sprouting following irradiation of a tropical rain forest. In: Odum HT, Pigeon RF (eds) A tropical rain forest: a study of irradiation and ecology at El Verde, Puerto Rico. National Technical Information Service, Springfield, pp D305-D308

Koo FKS, De Irizarry ER (1970) Nuclear volume and radiosensitivity of plant species at El Verde. In: Odum HT, Pigeon RF (eds) A tropical rain forest: a study of irradiation and ecology at El Verde, Puerto Rico. National Technical Information Service, Springfield, pp G15-G20

Larsen MC, Torres Sánchez AJ (1998) The frequency and distribution of recent landslides in three montane tropical regions of Puerto Rico. Geomorphology 24:309-331

Lugo AE (1978) Stress and ecosystems. In: Thorp JH, Gibbons JW (eds) Energy and environmental stress in aquatic systems. National Technical Information Services, Springfield, pp 62-101

Lugo AE (1988) Ecological aspects of catastrophes in Caribbean islands. Acta Científica 2:24-31

Lugo AE (1996) Ninety years of plant ecology research in Puerto Rico. Ann N Y Acad Sci 776:73-88

Lugo AE (2008) Visible and invisible effects of hurricanes on forest ecosystems: an international review. Austral Ecol 33:368-398

Lugo AE, Heartsill Scalley T (2014) Research in the Luquillo Experimental Forest has advanced understanding of tropical forests and resolved management issues. In: Hayes DC, Stout SL, Crawford RH, Hoover AP (eds). USDA Forest Service experimental forests and ranges: research for the long-term. Springer, New York, pp 435-461, 672 pp

Lugo AE, Helmer E (2004) Emerging forests on abandoned land: Puerto Rico's new forests. For Ecol Manag 190:145-161

Lugo AE, Brown S, Brinson MM (1990) Concepts in wetland ecology. In: Lugo AE, Brinson MM, Brown S (eds) Forested wetlands. Elsevier, New York, pp 53-85

Lugo AE, Rogers CS, Nixon SW (2000) Hurricanes, coral reefs and rainforests: resistance, ruin, and recovery in the Caribbean. Ambio 29:106-114

Lugo AE, Ramos Álvarez A, Mercado A, Feliciano DLL, Cintrón G, Márquez D’Acunti L, Chaparro R, Fernández Porto J, Peisch SJ, Rivera Santana J (2004) Cartilla de la zona marítimo-terrestre. Acta Científica 18:1-148

Lugo AE, Nytch CJ, Ramsey M (2013) An analysis of the US Army Corps of Engineers documents supporting the channelization of the Río Piedras. Acta Científica 27:4-72

McCormick JF (1970) Patterns of radiation exposure in the tropical rain forest. In: Odum HT, Pigeon RF (eds) A tropical rain forest. National Technical Information Service, Springfield, pp C41-C47

Méndez Lázaro PA, Pérez Cardona CM, Rodríguez E, Martínez O, Taboas M, Bocanegra A, Méndez Tejeda R (2016)
Climate change, heat, and mortality in the tropical urban area of San Juan, Puerto Rico. Int J Biometeorol. https:// doi.org/10.1007/s00484-016-1291-Z

Méndez Lázaro P, Muller Karger FE, Otis D, McCarthy MJ, Rodríguez E (2017) A heat vulnerability index to improve urban public health management in San Juan, Puerto Rico. Int J Biometeorol. https://doi.org/10.1007/s00484-0171319-z

Mercado N (1970) Leaf growth, leaf survival, leaf holes, color of cambium, and terminal bud conditions. In: Odum HT, Pigeon RF (eds) A tropical rain forest: a study of irradiation and ecology at El Verde, Puerto Rico. National Technical Information Service, Springfield, pp D271-D286

Muñoz-Erickson TA, Lugo AE, Quintero B (2014) Emerging synthesis themes from the study of social-ecological systems of a tropical city. Ecol Soc 19:23

Odum HT (1970) Microscopic order in the forest. In: Odum HT, Pigeon RF (eds) A tropical rain forest: a study of irradiation and ecology at El Verde, Puerto Rico. National Technical Information Service, Springfield, pp G3-G14

Odum HT (1996) Environmental accounting. EMERGY and environmental decision making. Wiley, New York

Odum HT, Drewry G (1970) The cesium source at El Verde. In: Odum HT, Pigeon RF (eds) A tropical rain forest. National Technical Information Service, Springfield, pp C23-C36

Peters DPC, Lugo AE, Chapin SS III, Pickett STA, Duniway M, Rocha AV, Swanson FJ, Laney C, Jones J (2011) Crosssystem comparisons elucidate disturbance complexities and generalities. Ecosphere 2:Article 81

Picó R (1969) La nueva geografía de Puerto Rico. Editorial Universitaria. Universidad de Puerto Rico, Río Piedras

Scatena FN, Larsen MC (1991) Physical aspects of Hurricane Hugo in Puerto Rico. Biotropica 23:317-323

Thompson J, Brokaw N, Zimmerman JK, Waide RB, Everham EM III, Lodge DJ, Taylor CM, García Montiel D, Fluet M (2002) Land use history, environment, and tree composition in a tropical forest. Ecol Appl 12:1344-1363

Venator R, Koo FKS (1970) Inherent and radiation-induced cytological abnormalities in Palicourea riparia Benth. In: Odum HT, Pigeon RF (eds) A tropical rain forest: a study of irradiation and ecology at El Verde, Puerto Rico. National Technical Information Service, Springfield, pp G21-G38

Wadsworth FH (1950) Notes on the climax forests of Puerto Rico and their destruction and conservation prior to 1900 . Caribb For January:38-47

Walker LR, Shiels AB (2013) Landslide ecology. Cambridge University Press, Cambridge

Watson H (1970) Branch elongation and the radiation field. In: Odum HT, Pigeon RF (eds) A tropical rain forest: a study of irradiation and ecology at El Verde, Puerto Rico. National Technical Information Service, Springfield, pp D287D294

White PS, Pickett STA (1985) Natural disturbance and patch dynamics: an introduction. In: Pickett STA, White PS (eds) The ecology of natural disturbance and patch dynamics. Academic Press, New York, pp 3-13 